University at Buffalo School of Law

Digital Commons @ University at Buffalo School of Law

2-1-2010

\title{
Women Lawyers, Women's Rights in Senegal: The Association of Senegalese Women Lawyers
}

Judy Scales-Trent

University at Buffalo School of Law

Follow this and additional works at: https://digitalcommons.law.buffalo.edu/journal_articles

Part of the Human Rights Law Commons

\section{Recommended Citation}

Judy Scales-Trent, Women Lawyers, Women's Rights in Senegal: The Association of Senegalese Women Lawyers, 32 Hum. Rts. Q. 115 (2010).

Available at: https://digitalcommons.law.buffalo.edu/journal_articles/881

Copyright (c) 2010 The Johns Hopkins University Press. This article was first published in Human Rights Quarterly 32.1 (2010), 115-143 Reprinted with permission by Johns Hopkins University Press.

\section{IN COPYRIGHT}

This Article is brought to you for free and open access by the Faculty Scholarship at Digital Commons @ University at Buffalo School of Law. It has been accepted for inclusion in Journal Articles by an authorized administrator of Digital Commons @ University at Buffalo School of Law. For more information, please contact lawscholar@buffalo.edu. 


\title{
HUMAN RIGHTS QUARTERLY
}

\section{Women Lawyers, Women's Rights in Senegal: The Association of Senegalese Women Lawyers}

\author{
Judy Scales-Trent*
}

\begin{abstract}
L'Association des Femmes Juristes Sénégalaises (The Association of Senegalese Women Lawyers) has been working to improve the lives of women in Senegal for almost forty years. In a predominantly Muslim country where most women do not even attend high school, these women have used their legal skills to make change. With little money, no paid attorneys on staff, and using a borrowed room in a law firm as an office, they have successfully pushed the government to make positive changes in the Family Code and other laws and have played an important role in the development of human rights consciousness in Senegal.
\end{abstract}

* Judy Scales-Trent is Professor Emerita and former Floyd H. and Hilda L. Hurst Faculty Scholar, at the State University at Buffalo School of Law. She was the recipient of a Fulbright Fellowship to Senegal in 2000-2001, where she taught law school at Université Cheikh Anta Diop de Dakar, and began a research project on women lawyers in that country.

This research was funded in part by a Fulbright Fellowship and a grant from the Baldy Center for Law and Social Policy. I am grateful to Marie Delphine Ndiaye and Nafissatou Diouf Mbodj, present and former presidents of the Association of Senegalese Women Lawyers, who encouraged this work and gave me access to Association documents. My thanks go also to Executive Secretary Aminata Kébé who provided so much information, and to all those who took time out of their busy lives for an interview.

I also express my appreciation to colleagues who commented on an earlier version of this article: Papa Demba Fall, Marième Lô, Isabel Marcus, and Wilma Randle. Thanks also to Hichem Kéfi, who clarified intricacies of the francophone legal system and helped me translate French legal terms.

And finally, I offer my warmest gratitude to Papa Demba Fall and the extended Fall family. Without their extraordinary generosity and kindness over the years, this article would not have been written. 


\section{INTRODUCTION}

On 17 January 2007, at the military school in Ouakam, Senegal, General Abdoulaye Fall welcomed the thirty-ninth entering class of trainees to become gendarmes, members of the state police. The class included fifty women. These young women, selected out of 2,700 female applicants, would be trained along with 500 young men. During his welcoming speech, General Fall told those present that "this entering class . . . is the first experiment for integration of young women into our ranks, and I want it to succeed."1

Before 2007, Senegalese law stated that only men could be gendarmes. The Association of Senegalese Women Lawyers (AJS or Association) spent many years trying to convince the government to change this law. ${ }^{2}$ The fact that the military was now training both men and women to be gendarmes was a great success for the organization. Indeed, the Association considers itself "godmother" to these young women. A few weeks after General Fall welcomed the women to the military school, the Association invited them to a ceremony in Dakar to honor them. Present at the ceremony were members of the Senegalese President's cabinet. During the ceremony, the Association presented each trainee with a medal, and the young women returned the gesture by giving the Association a photograph of themselves in uniform. ${ }^{3}$

This article is about the Association of Women Lawyers in Senegal (AJS), a group of well-educated women in a country where most women do not even attend secondary school. It describes the work they do to improve the lives of women in Senegal. In addition, this article is a case study of how one organization in civil society-in a particular context, with particular pressures-maneuvers in the space between religion and the state, tries to maintain its legitimacy, and, at the same time, serves and represents women within multiple legal systems. This article will address several questions: What is AJS? Why was it created? What are its goals? What issues have these women lawyers been addressing over the years? And what are their plans for the future?

The second section of this article describes the creation of the organization in 1974 as well as the reasons for its creation. It explains how the organization is structured, how it operates, and how it is funded. It also describes how AJS works with other groups, including Senegalese women's

1. Gendarmerie: Les femmes en bleu arrivent, Sud QUOTIDIEN, 8 Jan. 2007, available at http://www.seneweb.com/news/engine/print_article.php?artid=7991.

2. In its own documents, the Association refers to itself as both Association des Juristes Sénégalaises and Association des Femmes Juristes Sénégalaises. It uses AJS as its acronym.

3. L'Association des Femmes Juristes du Sénégal (AJS), Rapport Journée de Consultation Juridique Gratuite 10 Février 2007 Sur Financement du Governement Américain 4 (2007) [hereinafter AJS, RAPPORT JOURnÉE], available at http://www.seneweb.com/news/engine/print_article. php?artid=7991. 
groups, the government, and international organizations.

A review of AJS documents over the past four years shows that the Association works to meet its organizational goals in essentially three ways: by providing information about the law and women's rights, by providing free legal advice, and by working to get discriminatory laws changed. The second section offers examples of their work in these areas.

Section three explores the issues that AJS has been addressing over the past years. The first cluster of issues grows out of Senegal's Family Code. After Senegal obtained its independence from France in 1960, it began to harmonize the traditional family law of its many ethnic groups with both Western and Muslim family law. The result of this effort was the Family Code. AJS has been successful in getting women-friendly changes to the Code over the years. This section will describe the Code provisions AJS has been able to change and those it has not. This section will also address abortion rights and rape, issues that are not addressed in the Code, but are of concern to the Association.

The last section of the article looks at the Association's plans for the future. It also examines those factors that make its work difficult, including both funding problems and the socio-religious context within which it works.

The article concludes with a summary and some thoughts about the nature of AJS. What kind of organization is it? Is it similar to a public interest law firm or a bar association? And what about government contributions to AJS? Do they limit AJS' independence? Finally, this article closes with a discussion of the possible impact that the growing Islamization in Senegal may have on the work of the Association. ${ }^{4}$

In order to understand the work of the Association, one must understand the context within which it works. The next section of this article will provide a brief description of Senegal: its people, the economy and government, women's lives, and the role of religion in the country. It will also explain the difference between a juriste in Senegal and a lawyer in the United States.

4. I conducted most of this research during two trips to Dakar in 2007 and 2008, during which I interviewed AJS officers and a founding member of the Association. I also met with the Dean of the law school at Université Cheikh Anta Diop de Dakar as well as staff members of the Ministry of Justice, the Office of the President of the Bar Association, and the National Agency for Statistics and Demography. I attended two AJS meetings and reviewed many of its documents. 


\section{CONTEXT}

\section{A. Senegal}

Senegal is a small country on the Atlantic coast of Africa, just south of the Sahara, with a population of about 13 million. ${ }^{5}$ About 75 percent of the population lives in the countryside; 60 percent of the population is farmers. ${ }^{6}$ The expansion of the Sahara desert, less rain, and soil erosion have all contributed to rural exodus. ${ }^{7}$ As a result, about a quarter of the Senegalese population now lives in or near Dakar, the capital. ${ }^{8}$

Although about 95 percent of Senegalese are Muslim, Senegal is a secular state. ${ }^{9}$ Islam has been present in the Senegambian region since the eleventh century. It grew slowly until the eighteenth century, when the destruction of the existing social and political order by the French led to widespread conversion to this new social structure. ${ }^{10}$ As Leonardo Villalón has noted: "Religious and political structures in colonial Senegal arose simultaneously and were formed and developed alternately in collaboration with and in opposition to each other."11 In his view, Senegal's well-publicized stability is due to the fact that the Islamic brotherhoods in that country have created a powerful religious structure that counter-balances the power of the state. ${ }^{12}$

The 2001 Constitution created a very strong presidency, a weak legislature, and a judiciary that, according to one constitutional scholar, functions more as a branch of the executive. ${ }^{13}$ Amnesty International recently criticized the Senegalese government for harassing the President's political opponents and for targeting journalists and writers critical of the government. ${ }^{14}$ Indeed, the President has been willing to exert great authority against those who

5. U.S. Dept. of State, Bureau of African Affairs, Background Note: Senegal, available at http://www.state.gov/r/pa/ei/bgn/2862.htm.

6. Marième Diop Dieye, consultant, expert in decentralization and local development, Communication sur l'Accès des Femmes à la Terre, Address to the AJS Conference 2 ( 6 Mar. 2008) (on file with author).

7. Sheldon Gellar, Democracy in Senegal: Tocquevillian Analytics in Africa 15 (2005).

8. Jean-Paul Minivielle, Amadou Diop \& Aminata Niang, la Pauvreté au Sénégal: des statistiques à LA RÉALITÉ 122 (2005).

9. U.S. Dept. of State, supra note 5.

10. Leonardo A. Villalón, Islamic Society and State Power in Senegal: Disciples and Citizens in Fatick 61 (1995).

11. Id. at 203

12. Id. at 25-27.

13. Ismalla Madior Fall, Évolution Constitutionnelle du SénéGal: De la Veille de L'Indépendance aux ÉLECTIONS DE 2007, at 107, 112 (2007). There have been three previous constitutions, all of which came into existence between 1959 and 1963. Id. at 7.

14. Amnesty Int'L, Human Rights in Republic of Senegal Report 2007, available at http://www.

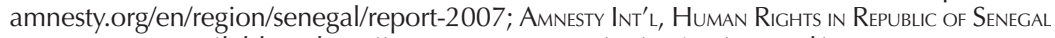
REPORT 2008, available at http://www.amnesty.org/en/region/senegal/report-2008. 
oppose him. For example, in 2008, President Abdoulaye Wade modified the Constitution to give him the authority to remove the president of the National Assembly because the National Assembly president had asked President Wade's son to appear before the legislature to give an accounting of public money spent organizing the Islamic Summit. ${ }^{15}$

The economic situation in Senegal is not good. There have been many contributing factors, including decades of drought and the privatization of the economy under structural adjustment programs demanded by the World Bank and the International Monetary Fund. ${ }^{16}$ Many Senegalese leave Senegal every year to find work in other countries in order to send money back home. In 2000, 20 percent of all Senegalese lived in other countries. ${ }^{17}$

The effect of the economic crisis in the country on women is exacerbated by the time-consuming and burdensome nature of their domestic chores. Because so few households have running water or electricity, women spend a great amount of time getting water for the household, washing clothes by hand, and grinding grain by hand. ${ }^{18}$ In the countryside, in addition to completing her domestic tasks, a woman is also obligated to work on her husband's land and the land of the family. Over half of the farmers in the country are women. ${ }^{19}$

Senegal dedicates more than a third of its budget to education. ${ }^{20}$ School is mandatory for children between the ages of seven and fourteen. However in 2004, more than half of the girls in that age bracket had never been to school. ${ }^{21}$ Many of the girls who attend school abandon their studies because of early marriages and pregnancies. ${ }^{22}$ They also leave because their mothers need help with the household or because they need to earn money for the

15. Ndiga Ndiaye, Les fondements de la République à l'épreuve du pouvoir de Me Wade (22 Nov. 2008), available at http://guissguiss.over-blog.com/pages/Les_fondements_ de_la_Republique_a_lepreuve_du_pouvoir_de_Me_Wade-882004.html; Le Parlement sénégalais adopte la loi réduisant le mandat de ses présidents (13 Oct. 2008), available at http://gaboneco.com/show_article.php?IDActu=10481.

16. Fatou Sow, Fundamentalisms, Globalisation and Women's Human Rights in Senegal, 11 Gender \& Dev. 69 (2003) [hereinafter Sow, Fundamentalisms].

17. Papa Demba Fall, International Labour Migration and Local Development in the Upper Valley of the Senegal River: The Premises of a New Citizenship 2 (Nov. 2005) (unpublished manuscript on file with author).

18. République du Sénégal, Ministère de l'Économie et des Finances, Agence Nationale de la Statistique et de la Démographie, Résultats du Troisième Recensement Général de la Population et de L'HABITAT-2002, at 109, 111 (2006) [hereinafter ANSD] (55 percent of households have running water and 41 percent of households have electricity), available at http://siteresources.worldbank.org/INTSENEGALINFRENCH/Resources/461584-1175072268436/ TROISIEMERECENSEMENTPOPULATIONETHABITATSENEGAL.pdf.

19. Dieye, supra note 6 , at $2-3$.

20. République du Sénégal, Ministère de l'Économie et Finances, Direction de la Prévision et de la Statistique, Rapport de Synthèse de la Deuxième Enquête SénéGalaise auprès des Ménages 71 (2004) [hereinafter ESAM].

21. Id.

22. Id. at 71 . 
family. A government survey in 2002 indicated that over half of the women in the country had no formal schooling. Only 11 percent of women had attended secondary school, and only 6 percent had attended a university. ${ }^{23}$

The 2001 Constitution provides many formal rights for women, including equality with men before the law, the right of access to land, and the right for women to control their own property. ${ }^{24}$ Senegal is also a signatory to important international conventions on the rights of women and girls, including the UN Convention on the Elimination of all Forms of Discrimination against Women (CEDAW). In 1999, influenced by CEDAW, Senegal enacted a law forbidding pedophilia, domestic violence, female genital mutilation, and sexual harassment. ${ }^{25}$ It also provided more severe sanctions for rape. Since then, training for judges has included a module on violence against women. ${ }^{26}$ Unfortunately, Senegal often fails to file update reports required by the international conventions and protocols to which it is a signatory and has also often failed to harmonize its national laws with the provisions mandated in the international conventions and protocols. ${ }^{27}$

President Wade played an important role in convincing the African Union to adopt the Solemn Declaration on Gender Equity in Africa in 2004. ${ }^{28} \mathrm{He}$ has since tried to get parity for women when political parties slate candidates for the legislature. ${ }^{29}$ In March 2006, President Wade selected the Association to be his advisor on legal issues involving women. ${ }^{30}$

\section{B. Lawyers and Juristes}

Although I have been using the words "lawyer" and "juriste" as synonyms, they are not. In Senegal, a juriste is anyone who passed the baccalaureate

23. ANSD, supra note 18 , at 63-64.

24. Constitution de la République du SénéGal, arts. 7, 15, 19.

25. eCOWas Gender Development Centre, Rapport Final: Réunion Consultative Organisée par le Centre de la CeDEeaO pour le développement du genre, en collaboration avec l'UNifeM et les membres de la Fédération des Juristes Africaines des pays membres de la CEDEAO 60-61 (2006). CEDEAO is the French translation of the English acronym ECOWAS or Economic Community of West African States.

26. Id. at 60-61.

27. FALL, supra note 13 , at 126 .

28. Aïda Mbodj, La Révolution, in République du Sénégal, Ministère de la Femme, de la Famille, du Développement Social et de l'Entreprenariat Féminin, Quinzaine nationale de LA Femme, Apr. 2007, at 3.

29. Abdoulaye Wade, l'Appel du chef de l'Etat pour la parité dans les institutions, QuinZAINE nationale de la Femme, Apr. 2007, at 13.

30. République du Sénégal, Ministère de la Femme, de la Famille et du Développement Social, Rapport du SénéGal sur la mise en oeuvre de la Déclaration solonnelle des chefs d'état et de Gouvernement sur l'ÉGalité entre les hommes et les femmes en AfriQue 2 (2006) [hereinafter Ministère de LA Femme, Rapport du SénéGal]. 
exam at the end of secondary school with a very high grade and then successfully completed four years of study at a law school. At the end of that four-year period, the student receives a master's degree. Anyone with this degree is a juriste. ${ }^{31}$

Juristes may choose to continue their studies to become a barrister, solicitor, or a judge. To become a barrister, a student must pass an aptitude test with a very high grade and then spend three years in an unpaid apprenticeship with a law firm, while taking classes at the Senegalese Training Center for Barristers. If, after three years, the report from the law firm is positive, she will be admitted to the bar. The same type of process is required to become a solicitor or judge. ${ }^{32}$

The term juriste thus encompasses many different job titles as well as job functions. It includes those who continue their studies after four years and those who do not; it includes not only barristers, solicitors, and judges, but also, inter alia, in-house lawyers, government lawyers, judicial law clerks, tax experts, and law school professors. In 2007, there were ninety-two women in their fourth year of study at the law school in Dakar who were about to become juristes. ${ }^{33}$

Every year in Senegal, only five or six students complete the long training process to become a barrister. Typically, only one of them is a woman. From the beginning of 2007 to the end of 2008, Senegal had approximately 300-350 barristers in the entire country, including those in training, but excluding those who worked in government or business. Of that number, only forty-five were women. ${ }^{34}$ There were also 418 judges in Senegal, of whom sixty were women. ${ }^{35}$

\section{THE ASSOCIATION OF SENEGALESE WOMEN LAWYERS}

\section{A. What Is AJS?}

In the early 1970s, professional women in Senegal began to create associations to address women's issues. Among these professional women were three women juristes, Madeleine Devès Senghor, Tamaro Touré Diallo, and

31. Interview with member of staff of Moussa Félix Sô, President of the Bar in Dakar (30 May 2007). He asked that his name not be used as he was only a representative of the Bar President.

32. Id.

33. Statistics provided by the administration of the law school at UCAD, 1 Mar. 2008. There are two other law schools in Senegal. I conducted research at only this school.

34. Interview with member of Moussa Félix Sô's staff, supra note 31.

35. Interview with Ahmadou Tall, staff member, Ministry of Justice, in Dakar (25 Feb. 2008). 
Maïmouna Ndongo Kane. ${ }^{36}$ In 1973, a year after the enactment of the Senegalese Family Code, these three women decided to create an organization of women lawyers. Two of them-Kane and Senghor-had already published articles about the legal issues affecting Senegalese women, ${ }^{37}$ but they were concerned about several provisions in the new Family Code that, in their view, restricted women's rights. They also thought that the general public should have more access to the law. The women discussed their ideas about forming an organization with then President of the Supreme Court, Kéba Mbaye, who encouraged the project..$^{38}$

One of the first things the women did was contact the International Federation of Women with Juridical Careers in Paris, which subsequently supported the creation of AJS and became its mentor. Soon after, AJS became one of the founding members of the Federation of African Women Jurists and sent representatives to the Federation's first meeting in Gabon. ${ }^{39}$ Working with the organization Women in Law and Development, the Association tried to create an organization that included all of the women juristes from the African continent, but language and cultural differences made this endeavor impossible. ${ }^{40}$ In 1978, the Association published a book titled Law in the Service of Justice, a collection of articles about women's and children's rights in Senegal. Three of the articles were written by Kane and Diallo, two of the founding members. ${ }^{41}$

By 2007, AJS had several goals:

to promote, popularize and contribute to the development of law;

to bring help, advice and training to the people;

to combat all forms of discrimination and work for equality in gender relations;

to contribute to the promotion and protection of children's rights;

36. In 1976, Maïmouna Ndongo Kane became the country's first Secretary of State for the Status of Women. Fatou Sow, Family and Law in Senegal: Continuity and Change, in Shifting Boundaries in Marriage and Divorce in Muslim Communities 153 (Homa Hoodfar ed., 1996) [hereinafter Sow, Family and Law in Senegal].

37. See Maïmouna Kane, The Status of Married Women Under Customary Law in Senegal, 20 Ам. J. Comp. L. 716 (1972); Madeleine Devès, Le Rôle de la Femme dans la Pratique du Droit Coutumier: Exemple du Sénégal, in Présence Africaine, La Civilisation de la Femme dans la Tradition Africaine 313 (1975).

38. Judge Mbaye also suggested that they start out as an amicale, an associative form that does not require filing documents with the state. They did so and became an association later on. Interview with Madeleine Devès Senghor, co-founder of AJS, in Dakar (27 Feb. 2008).

39. Id.

40. Fatou Sow, La recherche féministe et les défis de l'Afrique du XXIe siècle, in Pluralité et Convergences: La Recherche Féministe dans la Francophonie 423, 426 (Huguette Dagenais ed., 2005) [hereinafter Sow, La recherche féministe].

41. L'Amicale des Juristes Sénégalaises, La Parole aux femmes: Le Droit au service de la justice (1978). For a review of the book, see The Collected Edition of Roger Dorsinville's Postcolonial Literary Criticism in Africa: Vol. One: 1976-1981, at 195 (Max Dorsinvile ed., 2003). 
to sensitize public institutions and international organizations so that they will work to promote women, and to strengthen women's power and capacity for action;

and to work in partnership with any organization that has the same purposes, whether at the national, regional, or international level. ${ }^{42}$

In 2008, the Association had over 200 members, both women juristes and women law students. However, only about forty members were active. Most members live and work in Dakar. The Association's office is located in a law firm in Dakar, in a room donated by the firm. There are only two people on staff - the Executive Secretary and her assistant. Thus, volunteer juristes do all of the work related to the Association.

AJS holds meetings periodically throughout the year. ${ }^{43}$ The bylaws require a general assembly of all members at least once a year. ${ }^{44}$ The bylaws also explain that the financial resources of the Association include membership dues, gifts, payment for its publications, sale of Association property, and any other source for financing the work of the organization. ${ }^{45}$ Membership dues are approximately fifty dollars a year. ${ }^{46}$ AJS regularly sets up meetings with potential funders to try to find financing for its projects.

AJS works in conjunction with many different groups to plan conferences and develop strategies. For example, in 2002, AJS began a "Campaign for Women Citizens" with four other Senegalese women's groups. The campaign's goal was to help elect a large number of women during the local elections that spring. ${ }^{47}$ Other groups also include AJS in their plans. For example, when a journalist interviewed the President of the Committee to Fight against Violence against Women about the role of the courts in domestic violence cases, the President stated that when her organization did not have the money to represent women in court, she turned to AJS for help. ${ }^{48}$

AJS also works extensively with the national government. The Ministry of Women asked the Association to help it organize the first meeting of ministers

42. Guiliana Sera, Les Droits acquis de la femme sur le plan international, régional et national, LA CITOYENNE, July 2007, at 11.

43. Interview with Aminata Kébé, Executive Secretary of AJS, in Dakar (2 Feb. 2008).

44. AJS, Statuts de l'Association des Femmes Juristes Sénégalaises, art. 13 (16 Nov. 2007), available at http://femjursen.com/spip.php?article31 [hereinafter AJS, Statuts]. At the invitation of the Association, I attended both a monthly meeting on 19 Feb. 2008 and the General Assembly on 23 Feb. 2008 in Dakar.

45. Id. art. 22.

46. AJS, Conditions d'Adhesion, art. 1(3), available at http://femjursen.com/spip. php?article20.

47. Aminata Diaw, Les femmes à l'Épreuve du politique: permanences et changements, in Gouverner le Sénégal: Entre ajustement structurel et développement durable 244 (Momar Couba Diop ed., 2004).

48. Alain Tossounon, II existe des dispositions patriarcales dans le Code de la Famille (25 Mar. 2005), available at http://www.wluml.org/french/newsfulltxt.shtml?cmd\%5B157\% $5 \mathrm{D}=\mathrm{x}-157-149637$. The President of the Committee to Fight against Violence against Women was Oulimata Graye. 
charged with addressing gender issues within the government. The Ministry then asked the Association to help it develop and execute a plan. ${ }^{49}$ When the Association organized an "open door day" in 2007 to provide free legal advice, the Ministry of Women provided publicity for the event. ${ }^{50}$

The government has put AJS members on committees to revise the Penal Code and the Code of Criminal Procedure. When AJS was organizing the fifth Conference of the Federation of Lawyers in Dakar, the offices of both the President and Prime Minister provided technical and institutional support. ${ }^{51}$ And when the government wanted to send representatives to the United Nations Conference in New York to participate in the evaluation of global progress towards equality for women ten years after the Beijing Conference on Women, it selected members of the Association. ${ }^{52}$ In 2007, the Ministry of Foreign Affairs made AJS a member of the committee that the Ministry had formed to prepare for the Islamic Summit held in Dakar in 2008. ${ }^{53}$

In addition to its work within the country, AJS officers and members keep in touch with human rights groups in other countries by attending international conferences. When AJS does not have enough money to fund these trips, members pay their own way. ${ }^{54}$ Between 2004 and 2008, AJS representatives attended international conferences in Libya, Cape Verde, Italy, Ethiopia, United States, Spain, Portugal, and Gambia. ${ }^{55}$ By attending these conferences, AJS members have the opportunity to learn about progress on gender issues in other countries. For example, at the 2007 meeting of the Federation of African Women Jurists in Dakar, AJS members learned that in the Congo, not only are women in the army, but they also serve at fairly high levels and face no gender discrimination within the military. ${ }^{56}$ It is also possible that attending these meetings may provide an important sense of community to women activists who are often marginalized in their home countries and within their professions.

\section{B. How Does AJS Focus Its Work?}

The Association's bylaws require the organization to hold yearly meetings for the entire membership. At that meeting, the administrative council of AJS

49. Conseil d'Administration AJS, Assemblée Générale du samedi 28 janvier 2006, at 4 [hereinafter 2006 REPORT].

50. AJS, RAPPORT JOURnÉE, supra note 3, at 5 .

51. 2006 REPORT, supra note 49 , at 3-4.

52. Id. at $4-5$.

53. Conseil d'Addinistration AJS, Assemblée Générale du samedi 23 janvier 2008, at 8 [hereinafter 2008 Report]. Although the Association gives 23 January as the date for this meeting, it actually took place on 23 February.

54. 2006 REPORT, supra note 49, at 9.

55. Id. at 8-9; 2008 REPORT, supra note 53, at 10.

56. AJS, Rapport: Rencontre de la Fédération des Juristes Africaines 16 (2007). 
reports on the general operation of the Association. Members then vote on the budget and issues presented by the administration. ${ }^{57}$ For each general assembly, AJS administration prepares an extensive report of the work it has done since the previous assembly. As evidenced by the reports for 2006 and 2008, the Association concentrated its efforts on three tasks between 2004 and 2008: (1) providing information about the law, (2) providing free legal advice, and (3) trying to get Senegalese lawmakers to modify current laws so as to comply with both the Senegalese Constitution and international conventions to which Senegal is a signatory. ${ }^{58}$

\section{Providing information about the law:}

The Association provides information in different ways for different audiences. Because AJS works in a country with a low literacy rate and many national languages, it provides information about women's legal issues on radio and on television in both French and indigenous languages. ${ }^{59}$ From time to time, the Association has made regularly scheduled radio presentations during which issues discussed included divorce, inheritance, and domestic violence. ${ }^{60}$ Between April and July 2008, the current AJS president, Marie Delphine Ndiaye, made twelve weekly radio presentations on women's rights in Wolof. ${ }^{61}$ The Association has also met with the president of the Walfadjri Group, an important media outlet in Senegal, about establishing a partnership that would enable AJS to disseminate more information about the law through Walfadjri outlets. ${ }^{62}$

AJS members also travel throughout the country to give speeches to various groups. Recently, one AJS member went to Ziguinchor, a city in the southern region of Senegal that has been the site of a violent separatist movement. While there, she talked to women's groups about women's rights under international law in conflict zones, a cutting edge issue developed as a result of wars in Africa and the Balkans. ${ }^{63}$ In addition, members have traveled north to the law school in St-Louis every year since 2005 to talk

57. AJS, Statuts, supra note 44, arts. 12, 13.

58. 2006 REPORT, supra note 49; 2008 RePORT, supra note 53. The Association did not hold General Assembly meetings in 2005 or 2007, despite the requirements of its bylaws.

59. French is the official language of Senegal, and all public school education is conducted in French. National languages include Diola, Malinké, Pular, Serer, Soninké, and Wolof. See Constitution de la République du SénéGal, supra note 24, art. 1. On a Sunday evening while in Dakar, I happened upon a women's television show, "The Modern African Woman," where I saw then President of the Association Nafissatou Diouf Mbodj discussing women's legal issues in French and Wolof.

60. 2008 REPORT, supra note 53, at 3.

61. Telephone Interview with Marie Delphine Ndiaye, AJS President (18 Dec. 2008).

62. Conseil d'Administration AJS, Rapport d'Activités 2008, at 23 [hereinafter 2008 Activity REPORT].

63. 2008 REPORT, supra note 53, at 5-7. 
about the intersection of law and women's issues. ${ }^{64}$ In 2006 and 2007, AJS representatives also made presentations at the Pan-African Festival on Violence against Women. ${ }^{65}$ And in 2008, in conjunction with the Gambian film director Mariama Khan, the Association produced a documentary on rape, entitled "Sutura," which received a prize at that same festival. ${ }^{66}$

Another way AJS has disseminated information about women's rights is by publishing the magazine La Citoyenne (The Woman Citizen). Although the Association's original goal was to publish monthly, finding money to create the magazine has been difficult. As a result, since 2007, AJS has only published La Citoyenne twice. ${ }^{67}$ The July 2007 issue, funded by the American Embassy in Senegal, is a high quality magazine that includes the text of CEDAW, a report of a legal seminar organized by the Association, a guest editorial by a legal scholar on the principle of equity in Muslim law, Senegalese laws relevant to violence against women, an interview with the first Senegalese woman magistrate, and an article on the importance of making laws accessible in national languages. ${ }^{68}$

The Association also organizes day-long seminars and shorter evening seminars on legal issues. In March 2008, the day-long seminar concerned women's access to land. ${ }^{69}$ At the monthly meeting the week before the seminar, AJS members had a long discussion about the importance of having representatives of rural women at the seminar. AJS knew that it would have to fund these women's travel. Because the Association had a very small budget for the conference, several members of the Association made personal contributions to enable rural women to attend..$^{70} \mathrm{AJS}$ members also discussed the importance of ensuring that it had invited everyone who had anything to do with women's access to land, including members of the government, members of rural councils, and development partners. ${ }^{71}$

64. 2008 Activity Report, supra note 62, at 11-12.

65. 2008 REPORT, supra note 53 , at 3.

66. Sutura means "discretion." This festival, organized by the UN Population Fund and the Senegalese Ministry of the Family, takes place every November. AJS is a member of the committee that organizes the festival. 2008 Activity Report, supra note 62, at 27-28; Email from Aminata Kébé, Executive Secretary of AJS, to Judy Scales-Trent (21 Jan. 2009) (on file with author).

67. The Association plans to publish its third issue in March 2009. E-mail from Aminata Kébé, Executive Secretary of AJS, to Judy Scales-Trent (5 Jan. 2009) (on file with author).

68. LA CitOYenNe, July 2007.

69. An evening seminar in July 2008 addressed the issue of rape. See text at note 152 , infra. Les juristes sénégalaises décidées à combattre le viol (20 July 2008), (on file with author) [hereinafter Les juristes sénégalaises].

70. Author's notes of AJS meeting 2 Feb. 2008 (on file with author)[hereinafter Author's AJS Meeting Notes]. The Association budget for the conference was 3,075,000 FCFA, about $\$ 7,300.00$ in March 2008. The money would have to cover travel expenses for thirty-five women coming to Dakar from the countryside, honoraria for the legal expert and the representative of rural women, space and material at Hotel Teranga, and lunch for one hundred participants. AJS, Fiche Technique du Séminaire: Accès des Femmes à la Terre 5 (2008).

71. Author's AJS Meeting Notes, supra note 70. 
At the seminar, Marième Diop Dieye noted that although the Senegalese Constitution provides that men and women have equal rights to own land, there are many obstacles, including traditional modes of dividing land within a family, discriminatory agricultural policies, and the fact that generally, women do not know the laws about land ownership. ${ }^{72}$ Moreover, when women are given land, it is often either far from their home, bad land, or both. ${ }^{73}$ Adja Tiné Ndoye, President of the National Network of Rural Women in Senegal, pointed out that land decisions are made at the village level by men, and as families get larger and land has to be redistributed, the men often solve this by taking away land from women. If a woman asserts her right to own the land, her actions are considered to be an insult to her family's honor and to her husband. ${ }^{74}$ Land issues for widows are even more problematic because under traditional law, widows cannot inherit land from their husbands or fathers. ${ }^{75}$ Thus, traditional rules about land ownership still limit women's access to land, despite modern Senegalese property law and despite the country's Constitution.

The Association also provides information and training to its members so that they can be better lawyers and do better work for the Association. Between 2004 and 2006, AJS held a four day training session on the practice of banking litigation and the legal and organizational problems of running a non-profit organization. ${ }^{76}$ In 2007, the seminar focused on three issues: international conventions on the rights of women and children, the relationship between economic development and human rights, and techniques to strengthen the Association. ${ }^{77}$

In fall 2008, the Association was finally able to develop a website, www. femjursen.com. It had wanted a website for many years to better inform people about the work of AJS and the protection of women and children in Senegal. Association members also hoped that a website would improve communication with its development partners and facilitate its participation in national and international networks of women's rights organizations. ${ }^{78}$ Because it could not find a funder for this project, the current President of the Association, Marie Delphine Ndiaye, paid for the creation of the website. $^{79}$

72. Dieye, supra note 6 , at 1, 3-4.

73. Id. at 3-4.

74. Adja Tiné Ndoye, Accès des femmes rurales à la terre, Address to the AJS Conference 1-2 (6 Mar. 2008) (on file with author).

75. Id. at 1 .

76. 2006 REPORT, supra note 49 , at 3.

77. AJS, Séminaire de Formation de Formateurs 1 (2007).

78. 2008 REPORT, supra note 53, at 11.

79. 2008 ACTIVITY REPORT, supra note 62, at 27. 


\section{Providing free legal advice:}

Members of the Association have often provided free legal advice in the AJS office $^{80}$ and even, at times, leave Dakar to act as legal counsel for an individual. ${ }^{81}$ Between 2004 and 2008, AJS also set up five "open door days" in public venues in St-Louis, Dakar, and Pikine, a poor city on the outskirts of Dakar, to provide free legal advice. ${ }^{82}$ In 2007, volunteers at the "open door day" included judges, barristers, judicial law clerks, university professors, legal experts, and in-house counsel for businesses and banks. ${ }^{83}$ One hundred and one people came and requested legal advice. Interestingly, most were men. As they entered the room, volunteers directed them to the juriste who could help them with their particular issues. The most common legal questions involved property law, employment law, and family law issues, especially divorce, child custody, and inheritance. Some students came to ask questions about legal professions. ${ }^{84}$

AJS invited the Cabinet heads of the Ministry of Justice and the Ministry of Women to preside over the event. Also present were the UNICEF representative to Dakar, representatives of the High Command of Gendarmes, and the Association's "goddaughters" — the first women accepted into gendarme training. It was a day for legal advice, but AJS also used the day to honor UNICEF, the Ministry of Women, and the young gendarmes-in-training. ${ }^{85}$

In July 2008, sixteen members of the Association went to Rufisque, a small city near Dakar, to offer free legal advice in two venues. Their first stop was at a women's prison. Before discussing legal issues with the inmates, the Association members distributed gifts such as soap, rice, grooming products, milk, and mats. ${ }^{86}$ The food provided the prisoners with better meals than they otherwise would have received, and the mats gave them a place for their prayers as well as a place to relax. ${ }^{87}$ Association members then asked about the status of the inmates' cases, and the barristers promised to check on those cases that had not yet been decided to make sure that they were handled without delay. ${ }^{88}$ They then shared a light meal with the prisoners

80. 2008 REPORT, supra note 53, at 3.

81. Kébé Interview, supra note 43.

82. 2006 REPORT, supra note 49, at 2; 2008 REPORT, supra note 53, at 2; AJS, Compte Rendu de la Visite de I'AJS à I'Université Gaston Berger de Saint-Louis (report on file with author).

83. AJS, RAPPORT JOURnÉE, supra note 3, at 7.

84. Id. at 4 .

85. Id. at 2-4. The day was financed by the American Embassy. Id. at 1. As one would expect during a Senegalese event, the Association served a free lunch for everyone present at lunch time. Id. at 6.

86. AJS, Visite aux détenues de la prison pour femmes de Rufisque Samedi (5 Juillet 2008), available at http://femjursen.com/visites-aux-detenues.php [hereinafter AJS, Visite aux détenues].

87. E-mail from Aminata Kébé, Executive Secretary of AJS, to Judy Scales-Trent (13 Jan. 2009) (on file with author).

88. 2008 REPORT, supra note 53, at 2-3. 
and prison administrators. After leaving the prison, the Association members spent the afternoon offering free legal advice in a space provided by the Ministry of Justice. Sixty people came to ask legal questions about rape, domestic violence, divorce, and conflicts over land. ${ }^{89}$

The Senegalese government provides some free legal services. It has set up six "houses of justice" to which retired judges come twice a week to provide mediation services for domestic disputes. But even before the creation of these centers, the Association wanted to do more than hold sporadic "open door days." It wanted to create small law offices that would be open six days a week where women attorneys would not only mediate disputes, but would also provide information about the law, tell clients how to proceed with an issue, and even take cases to court. Members thought that a legal office run by women lawyers would encourage women to come in and ask for legal advice. They also thought that because AJS members are so committed to the protection of women's rights, they would be able to represent women better than male lawyers. ${ }^{90}$ For many years, the Association has tried to set up these small law offices in two areas of Dakar. AJS members met with the mayors of both of those sections of the city, who responded positively to the idea. Yet, AJS had trouble finding the money to set up an office and keep it running. Although the development agency of the French government had agreed to finance these small offices, they had not yet formalized an agreement. ${ }^{91}$

Finally, in July 2008, the AJS President announced that the development agency of the Italian government had agreed to finance the opening of a small law office in the Medina, a poor area of Dakar. ${ }^{92}$ As she later explained, the entire situation was a good example of AJS "partnership:" the mayor would provide free space for an office near city hall, the Italian development agency would pay for the material and labor to transform that space into an office and cover utilities for one year, and AJS members would take turns providing free legal advice at the office six days a week. The Association would not pay the lawyers unless a legal expert was needed for a specific problem. Even then, the expert would only receive about ten dollars. ${ }^{93}$

At the same time that Association members were arranging for the purchase of office equipment and the transformation of empty space into an office, they also met with the Association of Women in the Medina to explain the purpose of the office and to involve it in the official opening ceremony. ${ }^{94}$ The law office opened its doors on 1 December $2008 .{ }^{95}$ Pres-

89. AJS, Visite aux détenues, supra note 86.

90. E-mails from Aminata Kébé, Executive Secretary of AJS, to Judy Scales-Trent (5, 19, 20 Jan. 2009) (on file with author).

91. 2006 REPORT, supra note 49, at 15; 2008 REPORT, supra note 53, at 16.

92. Les juristes sénégalaises, supra note 69.

93. Telephone Interview with Marie Delphine Ndiaye, President of AJS (21 Nov. 2008).

94. 2008 Activity Report, supra note 62, at 23.

95. Ndiaye interview, supra note 93. 
ent at the inauguration ceremony were the cabinet director for the Ministry of Justice, a representative from the Ministry of Women, the director of the Italian development agency, and delegates from the neighborhood. During this event, the representative of the Ministry of Justice announced that with the help of the Association, the government planned to create six more small law offices of this kind. ${ }^{96}$

\section{Attempting to get Senegalese laws changed:}

Although the Senegalese Constitution of 2001 contains expansive sections pertaining to women's rights, as in many civil law countries, there are no related texts that provide for their enforcement. ${ }^{97}$ Constitutional rights in Senegal, therefore, are abstract in a way that they are not in the United States. ${ }^{98}$ In Senegalese jurisprudence, international laws ratified by the State take precedence over national law. ${ }^{99}$ As a result, instead of going to court to enforce women's constitutional rights, AJS works with the government to harmonize Senegalese law with the gender provisions in both the Senegalese Constitution and Senegal's treaty obligations.

Several years ago, AJS created committees to review the Family Code and the Penal Code to identify provisions in those texts that might be injurious to women's interests. ${ }^{100}$ AJS members have also reviewed tax laws, social security laws, workers' health benefit laws, and the Code of Nationality. ${ }^{101}$ Over the years, they have presented their analyses to the Prime Minister, the Ministry of Justice, and the head of the Ministry of Women. AJS members have met with the Prime Minister to present a document summarizing how to harmonize internal law with CEDAW. They have also discussed these issues with the High Council of the Republic for Economic and Social Affairs, at the request of that branch of the government. ${ }^{102}$

As previously noted, Senegalese law specifically excluded women from certain military jobs, including positions as soldiers, firemen, state police, forest rangers, and customs workers. ${ }^{103}$ AJS worked with the government for many years to get these laws changed. In 2006, the Senegalese government changed the laws to allow women access to these jobs, including positions with the state police, customs, and even the "special forces" group that is used to quell public disturbances. ${ }^{104}$

96. Pape Adama Touré, Boutique de Droit à la Médina: un réceptacle des soucis juridiques des femmes, PressAfrIK, 13 Dec. 2008, available at http://www.pressafrik.com/Boutiquede-Droit-a-la-Medina-un-receptacle-des-soucis-juridiques-des-femmes_a423.html.

97. Constitution de la République du Sénégal, supra note 24.

98. FALL, supra note 13, at 122-23.

99. Dior Fall, Parenté Conjointe au Sénégal: Plaidoyer Juridique, in Parenté Conjointe: Plaidoyer au SénéGal 18 (enda tiers-monde ed. 2002).

100. 2006 REPORT, supra note 49 , at 3.

101. See, e.g., Fall, supra note 99, at 13-33.

102. See 2006 RePORt, supra note 49, at 4-5, 2008 Report, supra note 53, at 7-8.

103. ECOWAS Gender Development Centre, supra note 25, at 63.

104. Mbodj, supra note 28, at 3. 


\section{What Are the Issues That Concern AJS?}

We have seen that after working many years to change exclusionary laws, the Association succeeded in getting some militarized jobs open to Senegalese women. But the issues that have most preoccupied AJS grow out of the Family Code.

In 1961, a year after Senegal's independence, then President Senghor created a commission to codify the law of the family. It took eleven years before the commission completed the Family Code ${ }^{105}$ so great were its complexities and so great were the political sensitivities surrounding this issue. Unfortunately, although President Senghor wanted both to secularize the code and to improve the lives of women, he created a twenty-seven person commission that included six Muslim clerics and no women. ${ }^{106}$

The Family Code, enacted in 1972, was an effort to create a modern uniform code, to secularize family law, and to make it applicable to all Senegalese, regardless of their religious affiliation. ${ }^{107}$ As one scholar notes, before its enactment, "legal matters concerning marriage, families, and property were negotiated with respect to Koranic law, traditional law, and ... French law."108

The new Family Code included some positive changes for women: it abolished Muslim tribunals, it required consent for marriage, and it required that marriage be registered. If a husband wanted to marry another woman during the life of the union with his current wife, the current wife had to agree to be part of the polygamous union at the time of their marriage ceremony. Husbands could no longer repudiate their wives if they wanted a divorce. They could only get a divorce in civil court. ${ }^{109}$ As Doudou Ndoye notes, families were rebalanced, and "husband/rulers" became "husbands/ limited by a judge."110

But President Senghor knew that in order to bring modern rules into the Family Code, he would need the approval of the powerful Muslim religious leaders in Senegal. ${ }^{111}$ Therefore, although Senegal is a secular state, the government provided the following instructions to the committee developing the Family Code:

Find a compromise, while making sure to distinguish what is of a truly religious nature from what is wrongly thought of as a religious rule in the event of opposi-

105. Fatou K. Camara, Women and the Law: A Critique of Senegalese Family Law, 13 Soc. IDENTITIES 787 (2007).

106. Id. at 798 .

107. Amsatou Sow Sidibé, Senegal's Evolving Family Law, 32 U. Louısville J. Fam. L. 421, 422, 426 (1993-1994).

108. Fatou Sow, Senegal: The Decade and its Consequences, Issue: J. OpINION at 34 (1989) [hereinafter Sow, Senegal].

109. Sow, Fundamentalisms, supra note 16, at 72 .

110. Doudou Ndoye, La Famille Sénégalaise et le Droit Moderne, Revue Internationale de Droit Africain 11 (Mar. 2001).

111. Id. at 11 . 
tion between the traditional status and the modern one. In the case of Muslim Law, only what is imperatively prescribed by the Quran will be applied. ${ }^{112}$

Because of this directive, the 1973 Family Code still contained provisions important in the Muslim tradition, including polygamy as a marital choice, the requirement that the husband be the head of the family, and unequal inheritance rules. One scholar suggests that the Code thereby perpetuated the patriarchy of both the Napoleonic Code and Islamic law. ${ }^{113}$ It is no wonder then that the women who founded AJS began to think about organizing for women's rights in 1973, a year after the Code's enactment. And AJS has been addressing the Family Code issues ever since.

AJS played a large role in getting changes beneficial to women put into the Code when it was revised in $1989 .{ }^{114}$ For example, before the revision, the Code stated that a husband could oppose his wife's choice of profession. ${ }^{115}$ The 1989 repeal of this provision meant that she was now free to make her own decisions about her professional life. Another new provision in the revised Code provided that a girl who was married while under the age of consent could have her marriage nullified, even if a child had been conceived during that marriage. ${ }^{116}$

Since the 1990s, AJS has focused on two other particularly problematic articles of the Code: Article 152 says that the husband is the head of the family, and Article 277 gives the father all authority over the children. As late as 2005, these articles had the following effects:

(1) The wife had no juridical capacity with respect to her children: Because she had no authority over her children, there were many actions she could not take with respect to her children, like authorizing medical care or buying tickets for travel. Although Article 277 provides that if the decisions taken by the father are contrary to the interests of the children or family, the mother may go to civil court and ask a judge to give her parental authority, this situation is very rare. ${ }^{117}$ Even when the father is willing to delegate authority to the wife, it is sometimes difficult because administrative authorities are unwilling to allow her to exercise that authority. ${ }^{118}$

(2) She paid more taxes than men in comparable situations. Because the father had all authority over the children, the law considered that a married woman

112. Camara, supra note 105, at 788 .

113. Sow, Family and Law in Senegal, supra note 36, at 150-51.

114. Sow, La recherche féministe, supra note 40, at 439. Another influence for change was Senegal's 1985 ratification of CEDAW. Aïda Soumaré Diop, Harmoniser les lois nationales avec les conventions internationales: une néccessité pour le Sénégal, in Parenté CONJOINTE, supra note 99, at 72.

115. Sow, Senegal, supra note 108 , at 34 .

116. Barbara Callaway \& lucy Creevey, The Heritage of Islam: Women, Religion, \& Politics in West Africa 181 (1994).

117. Fall, supra note 99, at 14; Camara, supra note 105, at 791-93.

118. Diop, supra note 114 , at 47 . 
with children had no children. Thus, women could not count their children as dependents for tax deductions: they received the same tax deduction as men with no children. ${ }^{119}$

(3) She received fewer benefits from the government than comparable men because in the eyes of the law she had no children. For example, Social Security law gives workers family allowances for each dependent child, but since only husbands have authority over children, mothers cannot get this allowance.120 Also, although the law provides an age limit for admission to the civil service, it extends that limit by a year for each dependent child of the job applicant. Unfortunately, since the Family Code implies that mothers have no dependent children, women cannot benefit from this law. ${ }^{121}$ Finally, the Senegalese law that provides medical benefits for workers states that it is available for workers' wives and children; it is therefore not available to the husband and children of working women. ${ }^{122}$

In 2002, in conjunction with the Institute for Peace and Human Rights at Université Cheikh Anta Diop de Dakar, AJS held a series of debates among religious leaders, scholars, and politicians on the issue of paternal authority. ${ }^{123}$ That same year, AJS conducted research on this issue at the request of the Environmental Development Action in the Third World (ENDA), which then published a collection of essays on paternal authority. ${ }^{124}$ The lead essay, written by an AJS member, cited Islamic authorities to support arguments for changing these code provisions and showed how these changes had been made to family codes in other francophone African countries. The author also suggested ways to modify these two provisions of the code, for example, by replacing the term "paternal authority" with "parental authority." 125 But the reaction to the idea of change was so hostile that the Association decided to set the project aside for the time being. ${ }^{126}$

By 2005, the government started to move on two issues: tax equity and the laws of health benefits. In 2006, the government changed the law concerning health benefits, thus enabling women workers to obtain health benefits for their husbands and children. ${ }^{127}$ In January 2008, the government passed a new law on fiscal equity that provides married women with children the same tax deductions as similarly situated married men. ${ }^{128}$

119. Fall, supra note 99 , at 15 .

120. Id. at 14 .

121. Id. at 15 .

122. Id.

123. Kébé interview, supra note 43.

124. ENDA, Rapport Final du projet Parenté conjointe 1, available at http://www.famafrique.org/ parenteconjointe/documentsecrits/rapfinal1.html.

125. Fall, supra note 99, at 29. In Burkina Faso, Togo, and Guinea, the law gives authority over the children to both parents. Id. at 30-32.

126. Kébé Interview, supra note 43.

127. Matou Sougou, Droits des Femmes et prise en charge médicale, LA Citorenne, July 2007, at 34.

128. Marie Delphine Ndiaye, I'Equité Genre: I'Année 2008 sous une nouvelle ère à travers l'équité fiscale, available at http://femjursen.com/articles.php. 
Despite these advances and all the efforts of the Association, AJS finds some provisions in the Family Code to be objectionable. The husband is still the head of the family and is vested with the authority to make decisions "in the common interest of the household and children." 129 The option to choose monogamy or polygamy at marriage is still in the Code and is still a male prerogative. ${ }^{130}$ Of great significance is the default rule, by which if a husband fails to choose monogamy or polygamy at marriage, the marriage is considered polygamous. ${ }^{131}$ In any event, even if the couple chooses monogamy at marriage, there are no penalties for the husband if he later takes another wife. With respect to inheritance, the Family Code still provides two options: the common law provision based on French law, in which the inheritance is equally divided among the children; and the auxiliary code based on Muslim law, in which daughters receive half of the amount the sons receive. ${ }^{132}$

The husband also still decides where the family will reside, and his wife is required to reside there with him. ${ }^{133}$ This is particularly difficult because Article 166 states that leaving the conjugal home is a civil offense and therefore grounds for not only divorce, but also for damages under Article 179. ${ }^{134}$ According to Article 177, if a wife is "to blame" for a divorce, she loses her right to alimony as well as to all gifts her husband ever gave her. ${ }^{135}$ These Code provisions put Senegalese women in a worse position than before the enactment of the Family Code because, traditionally, Senegalese women could choose their own dwelling and had the right to leave their husband whenever they so desired. ${ }^{136}$ Article 153 does provide that a spouse can ask a judge for permission to live in another place if she can prove that the household presents a moral or physical danger, but judges tend to interpret this provision in a harsh manner. ${ }^{137}$ In its publication $\mathrm{La}$ Citoyenne, AJS commented on the case of a twelve year old girl sentenced to six months in jail and fined for deserting the marital home, even though the legal age for marriage is sixteen, and even though she claimed abuse. ${ }^{138}$

129. Code de la Famille Sénégalaise, art. 152.

130. The Association has taken the position that monogamy is the preferred form of marriage, 2006 Report, supra note 49, at 5. The rate of polygamy in Senegal is declining. Between 1994 and 2004, the rate of polygamous marriages decreased from 41 percent to 25 percent, ESAM, supra note 20, at 33 .

131. Code de la Famillie Sénégalaise, art.133.

132. Amsatou Sow Sidibé, Le Pluralisme Juridique en Afrique: L’Exemple du Droit Successoral Sénégalais 47 (1991).

133. Code de la Famille Sénégalaise, art. 153.

134. Id. art. 179 .

135. Id. art. 177.

136. Camara, supra note 105 , at 795 .

137. Id. at 790-91. Camara calls the conjugal home "an unchosen prison for married women." Id.

138. Id. at 791-92. 
Regardless of the way courts handle these issues, going to court to settle a marital dispute instead of going to the head of the family is considered a serious offense to the family in Senegal. ${ }^{139}$

It is hard now to remember that when the Family Code was enacted in 1972 it contained many provisions to protect women: the requirement that women be at least sixteen years old to marry and consent to their marriage, the requirement that divorced husbands pay alimony and child support, and the end of repudiation. Unfortunately, many of these provisions are followed more in cities than they are in the rural areas where most Senegalese live. ${ }^{140}$ Moreover, few women know the rules of the Family Code that might protect them because the Code is written in French, and 90 percent of the population does not even speak French. ${ }^{141}$ Also, numerous Muslim leaders have told their adherents to simply ignore provisions that are contrary to Islamic teachings. ${ }^{142}$

AJS has found that many of the restrictive provisions in the Code that compromise women's equality within the family are proving to be difficult to change. This is not surprising. As one of the Association founders wrote in 1974, "[P] romoting women in her studies, work or politics is less traumatic for men than her emancipation as a wife."143 Nonetheless, whenever AJS representatives meet with staff from the Ministry of Women or Ministry of Justice, they raise these issues once more. ${ }^{144}$

\section{Non-Family Code Issues}

AJS continues to address statutory provisions in other codes that limit women's rights and control over their lives, including Article 9 of the Nationality Code, which provides that children cannot inherit their mother's nationality. ${ }^{145} \mathrm{An}-$ other of its major interests has been the restriction of abortion rights in the Senegalese Penal Code. Article 305 prohibits abortion. Any woman who had an abortion or tried to get an abortion may be sentenced to six months to two years in jail, in addition to paying a fine. Article 305 also punishes any person who assists in an abortion with a jail term for up to ten years plus a fine. ${ }^{146}$ This provision specifically includes doctors, pharmacists, herbalists, and sellers of surgical instruments, and requires that the professional licenses

139. Id. at 793 .

140. Sheldon Gellar, Senegal: An African Nation Between Islam and the West 123 (1995).

141. Camara, supra note 105, at 799.

142. Callaway \& Creevey, supra note 116 , at 178.

143. Maïmouna Kane, La protection des droits de la femme et le maintien de la famille sénégalaise, Revue SénéGalaise de Droit 40 (Dec. 1974).

144. Kébé Interview, supra note 43.

145. Fall, supra note 99, at 16.

146. Code Penal Sénégal, art. 305. 
of guilty individuals be suspended. Thus, even though half of emergency admissions to maternity wards are women who attempted to abort their fetuses at home or in a non-medical setting, doctors often refuse to care for these women for fear of fines, loss of license, and prison. ${ }^{147}$

Article 305 bis (Article 305(a)) goes even farther and makes it a criminal offense to persuade a woman to get an abortion, even if an abortion does not take place. ${ }^{148}$ This statute has broad implications and includes speaking in public, posting signs, or distributing material. Similarly, anyone who sells, offers for sale, or distributes any instruments or substances, knowing that they will be used for abortion, violates this provision. An individual violates this law even if an abortion was not attempted and even if these objects could not have caused an abortion.

According to AJS, these criminal provisions not only contradict the equality provisions of the Senegalese Constitution, but they also violate CEDAW provisions mandating that signatory states protect the reproductive rights of women by authorizing medical abortions in certain cases. ${ }^{149}$ The Association asserts that abortion should be legal in cases of rape or incest and also during the first months of pregnancy for all women who have serious health risks due to their pregnancies. ${ }^{150}$

AJS is also very concerned about the high numbers of rapes in Senegal. In March 2008 at the AJS General Assembly, one of the Association founders, Madeleine Devès Senghor, called on the Association to address this issue. ${ }^{151}$ Several months later, the Association held an evening seminar on rape, which statistics show is increasingly prevalent in Senegalese society. ${ }^{152}$ Speakers noted several problems with respect to combating this problem. One problem is that although rape victims need to go to the hospital immediately for an exam, this is often impossible because hospital tests and treatment are too expensive for the victim and her family. ${ }^{153}$ Immediate treatment is also difficult because of the small number of medical facilities in the country.

Furthermore, women who have been assaulted often refuse to complain to formal authorities because Senegalese society condemns those who go outside of the family to solve their problems. ${ }^{154}$ As one judge explained,

147. Aminata Kébé, Le Droit de l'Avortement au Sénégal 4-5, 8 (2008) (unpublished manuscript, on file with author).

148. Code Penal Sénégal, art. 305 bis.

149. Kébé, Le Droit de l'Avortement au Sénégal, supra note 147, at 11-21.

150. Id. at 28-29.

151. AJS, Projet de Procès-Verbal, Réunion de l'Assemblée Générale Ordinaire du 23 février 2008, at 2 (10 Mar. 2008).

152. Les juristes sénégalaises, supra note 69.

153. Id.

154. See, e.g., Amsatou Sow Sidibé, Les Discriminations à l'égard des femmes 3 (unpublished manuscript on file with author); Ministère de LA Femme, Rapport du SénéGal, supra note 30, at 7; Victimes de viol et $d^{\prime}$ inceste: les 4000 coups faits aux femmes (21 Nov. 2008) (article on file with the author). 
in European culture, human rights are those laws and rules that permit a person to protect himself from the group. Traditional African law, however, is conciliatory and draws on the desire for consensus and understanding within the group. Thus, in traditional African culture, staying away from the courtroom is a sign of wisdom and a reason to be proud of one's high moral standards and social behavior. ${ }^{155}$

Two weeks after the seminar on rape, the government announced the creation of a committee to study violence against women and children. According to the Minister of Justice, out of one hundred rape cases, forty-seven do not make it through the judicial system. In the Minister's view, factors causing this low percentage include slow procedures, the lack of assistance for the victims, and what he called "the law of silence." In addition, punishment for rape is so severe that judges often refuse to convict. ${ }^{156}$ The minister selected members of AJS to be on the committee. ${ }^{157}$

The committee's mandate includes addressing the issue of domestic violence. ${ }^{158} \mathrm{~A}$ study in 2000 showed that a quarter of Senegalese women are victims of domestic violence. Although the law provides for a penalty of up to five years in prison plus a fine for this crime, there are cultural reasons why more men are not convicted of the crime. As the head of UNIFEM in Senegal noted, Senegalese families often accept violence within the family, and a wife who learns how to live with the violence is sometimes considered to be a woman who functions well within the family. Also, according to a former Senegalese judge, judges have to deal with pressure from families to reduce the severity of the punishments because of economic reasons. ${ }^{159}$ The family simply needs the husband out of jail so that he can work and provide for it.

AJS has also been trying for some time to get the Commission on the Reform of the Penal Code to recommend enacting a law that would allow associations to join their clients as parties in civil suits. As a civil party, the Association would not only have access to information as the criminal phase progresses and be able to request further investigation, it would also be able to continue the suit if the victim decides to withdraw charges due to social pressure. ${ }^{160}$ In 2006, the Minister of Women suggested that the Association be named a civil party to each criminal case that involved violence against

155. Keba Mbaye, Les Droits de l'Homme en Afrique 54 (1992).

156. Maître Madicke Niang ministre de la Justice: '47\% des auteurs de viols sont impunis,' Nettalı.net, 12 Dec. 2008, available at http://www.seneweb.com/news/engine/print_article. php?artid=20004.

157. Adama Ly Diouf, Madické Niang sous-estime l'efficacité de la lutte contre les violences faites aux femmes, Agence de Press SénÉGAlAise, 11 Dec. 2008, available at http://www.aps. sn/aps.php?page=article\&id_article $=50204$.

158. Id.

159. Sénégal: Des femmes battues en silence (17 June 2008) (article on file with author).

160. Aminata Kébé, Les Soubassements juridiques de la constitution de Partie Civile pour les associations de défense des droits humains en cas de violence faite aux femmes et aux enfants 9-10 (2008) (unpublished manuscript on file with author). [hereinafter Les Soubassements juridiques de la constitution de Partie Civile.] 
women and girls. ${ }^{161}$ AJS provides two precedents in support of this unusual legal role. The first is a Senegalese law that gives human rights groups the authority to represent victims and become parties in trafficking cases. The second is the Optional Protocol to CEDAW, which provides that human rights groups that have exhausted their rights under national law may represent victims as a party to the case before the United Nations. ${ }^{162}$ Although the Commission on the Reform of the Penal Code did finally make this recommendation, the proposal has not yet become law. If it does become law, the Association plans to go to court for women who are victims of domestic violence, even if the women themselves do not go to court. ${ }^{163}$

\section{E. What Makes Their Work Difficult?}

The women of AJS have plans for the future. They want to continue publishing La Citoyenne as well as brochures on women's and children's rights. ${ }^{164}$ They want to expand their organization by creating a regional office in St-Louis. ${ }^{165}$ They would like to be able to translate Senegalese laws that are particularly important to the protection of women's rights from French into the national languages, a task not yet undertaken by the government. ${ }^{166}$ Lastly, they would like to find a "home" for the Association, which is currently housed in one room of a law firm in downtown Dakar. But all of this demands work and money, and both are in short supply.

Most of the AJS members are not actively involved in the work of the Association. As in many other organizations, only a few members do the majority of the work. At times, even those AJS members who agree to do a specific task do not do it. For example, AJS regularly creates committees to distribute work throughout the membership. In 2006, there were four committees with four tasks: research and training, the promotion of women's rights, the promotion of children's rights, and the organization of Association events. ${ }^{167}$ However, as then President Mbodj pointed out during the 2008 General Assembly, the committees did not function effectively and had not produced their respective reports for the meeting. ${ }^{168}$

161. La pudeur qui entoure la violence faite aux femmes est un vrai problème selon Aïda Mbodj (6 Mar. 2007) (article on file with author).

162. Kébé, Les Soubassements juridiques de la constitution de Partie Civile, supra note 160, at 12 .

163. Ndiaye interview, supra note 61.

164. 2008 REPORT, supra note 53 , at 13 .

165. E-mail from AJS to AJS members (30 May 2008) (on file with author).

166. Ndiaye interview, supra note 61.

167. See, e.g., 2006 RePORT, supra note 49 , at 7.

168. Notes taken by author at General Assembly, 23 Feb. 2008 (Dakar, Senegal) [hereinafter Author's GA Notes]. See also 2008 Report, supra note 53, at 16 (reports of committees not yet provided to AJS administration). 
Even if members were willing to do the work, the Association finds it difficult to raise money for AJS projects and the salaries of the two staff members. AJS does receive many in-kind gifts, like the loan of a room by a local law firm and the loan of space for monthly meetings by the Teranga Hotel in downtown Dakar. ${ }^{169}$ But AJS needs money to finance its projects, and many AJS members are behind on their dues. ${ }^{70}$ Thus, AJS continues its search for funding. Between 2006 and 2008, AJS discussed funding with many organizations including the Canadian and Spanish development agencies, the European Union, Trust Africa, the United Nations Population Fund, and the Konrad Adenauer Foundation. ${ }^{171}$ Over the years, as we have seen, they have successfully found development partners. For example, the American Embassy funded the publication of La Citoyenne, and the Italian development agency funded the creation and operation expenses for one small law office. However, despite these positive examples, AJS requests are often turned down.

Another difficulty AJS faces is working with other human rights associations. One issue that AJS addressed in a member training session was the lack of cohesion and teamwork among human rights associations. Several members noted that there was no framework for consultation and cooperation as a group. ${ }^{172}$ Similarly, one of the Association's development partners noted that women's associations in Senegal were characterized by conflict, competition, jealousy, and power struggles, which sometimes interfered with their ability to attain important objectives. ${ }^{173}$ Although this is not unusual in organizations, it still makes the work of the Association harder.

Finding people to do the work, finding money for the work, and working together with other groups all renders the work of AJS more difficult. Working to improve the lives of women in Senegal is also difficult because AJS is working within a socio-religious context that has elevated male status over traditional African matriarchal laws that empowered women. ${ }^{174}$ As a result, when AJS works to improve women's lives in Sengegal, it must demonstrate that its work is supported by Islamic law. For example, when an AJS member wrote an article on the need to change the Family Code requirement of paternal authority, she referred to research by Islamic scholars to show that Islamic jurisprudence provides no obstacle to joint parental authority. ${ }^{175}$ Similarly, in a speech on the importance of changing laws that prohibit abortion, Aminata Kébé discussed the importance of organizing workshops

169. Interview with Nafissatou Diouf Mbodj, then President of AJS (20 Feb. 2008).

170. Author's GA Notes, supra note 168.

171. 2008 REPORT, supra note 53, at 10; 2008 Activity RePort, supra note 62, at 23-27.

172. AJS, Séminaire de Formation de Formateurs, supra note 77 , at 3.

173. Sera, supra note 42 , at 11 .

174. Camara, supra note 105, at 789 .

175. Fall, Le Droit de l'Avortement au Sénégal, supra note 99, at 25-27. 
for religious people to help them understand this point of view. ${ }^{176}$ And the July 2007 issue of La Citoyenne included an article by a professor of Islamic law on the principle of equity in the Coran. ${ }^{177}$

\section{CONCLUSION}

The AJS is comprised of a small group of well-educated women in a very poor country who, since 1974, have continuously worked to improve women's lives in their country. They have managed to place women's issues on the political agenda and have sometimes even succeeded in persuading the state to protect women's rights. ${ }^{178}$ Using speeches, meetings, radio, television, publications, and free legal advice-working individually and with other groups in Dakar, around Senegal, and in other countries-AJS has made its mark. Scholars have noted the importance of its work in opening avenues for discussion of women's rights. As one scholar explains, AJS has participated in the development of "human rights consciousness." ${ }^{179}$ Scholars have also noted the impact of Association work on changing restrictive rules in the 1989 revision of the Family Code. ${ }^{180}$ Because of its contribution, other human rights groups ask for the Association's help with their own respective projects; ${ }^{181}$ and the Minister of Women has said that "if the Association of Senegalese Women Lawyers does not accompany the Ministry of Women as we do our work, our progress will not be guaranteed by law."182

Through a review of their work over the years, one can easily see the Association's commitment to improving women's lives in its country: members spend time and energy on Association projects, provide free legal advice, pay their own way to conferences, and pay for the AJS website. Through this review we can also see that the Association enjoys much respect within the larger Senegalese community. High-ranking officials do not hesitate to appear at its meetings and conferences. The President of the country chooses its members as his legal advisors on women's rights. Finally, it is hard not to notice that the Association is making very sophisticated choices about not only which controversial issue to address, but also when and how to address it.

176. Kébé, Le Droit de l'Avortement au Sénégal, supra note 147, at 27.

177. Abdoul Aziz Kébé, l'Equité et l'égalité de genre: le principe d'équité dans la législation musulmane, LA CitOYENNE, July 2007, at 8-9.

178. Scholars have noted that the role and impact of feminist organizations in Senegal is larger than their numbers would suggest. Callaway \& Creever, supra note 116, at 185.

179. Claude E. Welch, Jr., Protecting Human Rights in Africa: Roles and Strategies of Non-Governmental Organizations 290 (1995).

180. Sow, La recherche féministe, supra note 40, at 439-40.

181. See statement by Oulimata Gaye, supra note 48.

182. Interview with Nafissatou Diouf Mbodj, then President of AJS (23 Feb. 2008). 
It is interesting to think about the Association in comparison with human rights groups in the United States. For Americans, AJS appears to be a new kind of organizational group. In some ways, it acts like a public interest law firm: lawyers for AJS give legal advice, provide information on the law, and comment on government proposals for law reform while often working with other human rights groups. In other ways, AJS acts like a women's bar association: it organizes training sessions for women lawyers and sits on national committees on law reform. AJS members also act like attorneys in the US Justice Department: the President, the Prime Minister, and government agencies ask for their legal advice, and the government appoints Association members to represent Senegal before international organizations. In a sense, then, compared to US organizations, AJS is a hybrid organization whose members have decided to use their legal skills to advance the interests of women in their country and created an organization to enable them to do it.

In the United States, public interest law firm funding comes from private donors and foundations, bar association funding comes from dues, and government lawyers receive salaries. Similarly, AJS funding also comes from private donors, like the Teranga Hotel, or it comes from "foundations," like the development branch of the Italian government or the American Embassy in Dakar. It receives member dues like bar associations. And like the Justice Department, AJS also receives some funding and services from the government.

But this comparison raises the question of AJS independence from the government. In the United States, we are used to a more adversarial relationship between public interest law firms and the state. For example, the NAACP Legal Defense Fund has sued cities over school desegregation, and the American Civil Liberties Union has sued the FCC for controlling speech on the air. In Senegal, however, there is no legal mechanism for going to court to enforce constitutional rights; and in a country with a very strong president, the Association is perhaps wise to develop a political strategy that includes a close relationship with the government. However, this strategy raises the question of AJS independence from the government. In a situation where the government sometimes gives money and services to AJS, where the government sometimes asks AJS to work with its staff and represent the government in international meetings, and where the President of the republic has named AJS as his consultant on the law with respect to gender issues, how difficult is it for AJS to act independently of the government?

According to Association President Marie Delphine Ndiaye, remaining independent is not difficult at all. She suggests that the Wade government has provided some support because President Wade is a lawyer and likely understands the Association's work and needs. In addition, even though the President named the Association as his legal consultant on women's is- 
sues in 2005, he has not since contacted the Association for advice. If one looks at the thirty-five year history of the organization, one can see that the government has provided very little assistance to the organization. Ndiaye considers this lack of support positive, as there has therefore been no risk to the Association's independence. ${ }^{183}$

It is interesting to note that the Association and the government are engaged in a complicated unspoken dialogue, as each tries to use the other. The government put AJS members on the national committee charged with creating the program for the International Islamic Conference in 2008 in order to show that it was progressive about gender issues. However, it did not follow any of the Association's suggestions because it wanted to appease those countries that did not want to discuss changing gender roles within the Islamic world. The Association organized a day-long conference on rape and invited the media to cover it. Fifteen days later, the government announced the creation of a committee to study ways to reduce violence against women. The Association created the country's first free legal clinic, again, inviting media coverage. The government responded by announcing that it would create six more just like it. We don't know, of course, whether the government will follow the suggestions of the committee on violence against women, or whether it will indeed create those six legal clinics. But it does appear that the government pays some attention to what the Association is doing, just as the Association is paying some attention to the state.

In 2008, the Association had a banner year. It was finally able to open an office to provide free legal advice, it finally found the resources to create a website, it co-produced a film and published a second issue of its magazine, and it organized two very successful conferences. But even as AJS performs its functions and works out its relationship with the Senegalese government, it must do so in a society that is increasingly Islamicized. One reason for this "Islamic revitalization" is the increasingly poor economic condition in the country; ${ }^{184}$ and many Senegalese see the president as encouraging fundamentalism within the country. Fundamentalist groups are emerging. There is more and more Islamic preaching on both radio and television as Muslims demand a larger role in the public sphere. Not surprisingly, a particular focus of their demands is the role of women in society. They want women more secluded in domestic space, and they want women to wear the veil when they go out in public. ${ }^{185}$ As Villalón noted, the power of the Islamic brotherhoods balances the power of the state in Senegal. But that

183. Ndiaye interview, supra note 61.

184. Donna L. Perry, Wolof Women, Economic Liberalization, and the Crisis of Masculinity in Rural Senegal, 44 Ethnology 211, 222 (2005).

185. Sow, Fundamentalisms, supra note 16 , at 74-75. 
balance is not static. So while AJS is trying to better women's lives, there are forces in Senegalese society moving in the opposite direction.

Social change is hard. It takes a long time. It is often not even possible. And the Association of Senegalese Women Lawyers is only one actor in the very complicated fabric of Senegalese society. But in an interview with one of the founders of the organization, Madeline Devès Senghor provided an important perspective on the work of the Association. When asked what she considered the greatest success of the organization, she replied, "That it exists. That it exists and has continued to speak out for women after all these years." ${ }^{\prime 186}$

186. Senghor interview, supra note 38 . 